RESEARCH ARTICLE

\title{
Students as Contested: Exploring Issues of Student Identity and Identification in Educational Spaces
}

\author{
Ashley Kenwaya ${ }^{\text {*Phil Wilkinson }}{ }^{\mathrm{b}}$, and Kieron Dowden-Smith ${ }^{\mathrm{a}}$ \\ a Department of Computing, Bournemouth University, UK \\ ${ }^{b}$ Centre for Excellence in Media Practice, Bournemouth University, UK \\ Contact: pwilkinson@bournemouth.ac.uk
}

\begin{abstract}
This article explores issues of student identity and identification through a third-space theory lens. In addition, it positions this use of third-space theory as contributory to Students-as-Partners (SaP) approaches to teaching and learning. Naturally, this research was constructed as a SaP project, and research was undertaken as a collaboration between two undergraduate students and their lecturer. The literature review and student interviews presented here were conducted by the student co-researchers and interviews involved their BSc Cyber Security Management peers. These interviews unpacked constructions of student identity, student-lecturer relationships, and professional experiences. Thematic analysis of these interviews is presented reflectively with reference to student and lecturer perspectives. Finally, this article argues that for SaP to be successful it is necessary to critically examine the "student" identifier.
\end{abstract}

KEYWORDS

students-as-partners, cybersecurity, identity, education, third space

There is a shared belief among the authors that a Students-as-Partners (SaP) approach is beneficial to educational practices. Here we draw on third-space theory to articulate implications of the multiple student identities and identification processes that a SaP approach intersects with. In the study discussed here, a student co-researcher undertook interviews with second- and third-year undergraduate students to ascertain perspectives on their experiences of a BSc Cyber Security Management course. We identify a disconnect between the desires of participants to have their experiences across higher education (HE) and external to HE recognised, and a sense of resistance to the identification as a student.

Before we present our literature review, we first wish to address the way in which we have approached writing this paper. In assimilating our voices into a single first-person plurality, 
individual voices are lost. Crucially, given the need to conform to expected academic writing styles, the use of the first-person plural pronoun would perhaps result in the students' voices being more adversely dismissed than the lecturer's. To mediate this, we include frequent endnote-interruptions. In which we / they / I pull away from the plurality and pointedly include our / their / my reflections on the topic being discussed.

\section{LITERATURE REVIEW}

To begin, we discuss third-space theory, paying particularly attention to Bhabha's conceptualisation of identity formation as an externally influenced (Bhabha, 1994), if not externally led, process. Following this, we then address different ways that student identity is currently framed, with reference to broader notions of students-as-customers and employability. We then move on to discuss SaP, focusing initially on its conceptual definitions as a policy-backed ethos rather than discrete student-academic projects. ${ }^{1,2}$ In concluding this literature review, we identify the 'student' as a contested nexus of various identification and individual strategies of selfhood (Bhabha, 1994). Third-space theory, especially the work of Bhabha, becomes especially useful here in its framing of the student as a "hybrid" construction that is a potential source of tension.

\section{Identity construction in the Third Space}

We proposed the idea of a Third Space where teacher and student scripts - the formal and informal, the official and unofficial spaces of the learning environment-intersect. (Gutiérrez, 2008, p. 158)

Third-space theory has been applied to the understanding, or re-understanding, of educational spaces as intersectional. That is, the "classroom" is a nexus of different systems of meaning. As posited by Gutiérrez, student and teacher identity therefore becomes a multidimensional construct informed by various spaces including the "official" space of the classroom and the "unofficial" space of the home. To draw on the rhizomatic metaphor of Deleuze and Guattari (1987), as discussed by Bensen (2010), just as rhizomes grow from multiple points simultaneously, so too are there multiple significations of identity. Each signifier to an extent represents a "point of power" (Benson, 2010, p. 565).

Third-space theory then is a useful lens in SaP for two reasons. First it allows for the unpacking and problematising of student-teacher identity and relationships-a significant consideration given the necessity of equality and reciprocity in SaP projects (Cook-Sather, Bovill, \& Felten, 2014; Healy, Flint, \& Harrington, 2014; Mercer-mapstone et al., 2017). Second, it challenges the demarcation and stratification of educational spaces from other spaces, especially with regards to what is considered "legitimate' knowledge or expertise" (McDougall \& Potter, 2015, 2017). In combination, these two reasons extend the rhizomatic metaphor ${ }^{3}$ to refer to simultaneous, multi-directional growth, not necessarily limited to a single plant pot.

The fluidity of identity, and its influence by overlapping systems of meaning, is of relevance for this research. As first posited by Bhabha, third-space theory referred to the reconstruction of collective identities by oppressed people that resisted previous definitions of race, class, or other identity signifiers (Bhabha, 1994). That is, third-space theory refers to sites 
of contestation, populated with existential enactments of political resistance through which imposed identities are examined, challenged, and if not replaced, come to co-exist with new identities. In applying this third-space theory to educational settings, there is a consistent teleology of challenging previous, or inherited, identities, relationships, and broader constructions of society. For instance, Moje et al. (2004) argue that third-space theory should be "introduced in ways that challenge, destabilise, and, ultimately, expand the literacy practices that are typically valued in school and in the everyday world" (p. 44).

Indeed, there is a consistent application of third-space theory that refers to existing, or inevitable, conflicts with "schooled identity and the power dynamics of education" (McDougall \& Potter, 2017, p. 98). Given the importance of flattened hierarchies in SaP, Bhabha' $\mathrm{s}^{4}$ framing of identity as a response to external pressure is of significance. The term "student" as identification creates a potential existential imposition that overwrites other identifications. Or as Bhabha (1994) writes: "The question of identification is never the affirmation of a pre-given identity, never a self-fulfilling prophecy-it is always the production of an image of identity and the transformation of the subject in assuming that image" (p. 45).

Further, there is an implication of resistance here as students must interrogate this identification and reconcile it through their "strategies of selfhood" (Bhabha, 1994, p. 1) that are influenced by engagement with external systems of meaning. That is, the extent to which the "student" identification is contested is potentially informed through individual experiences of contexts external to higher education. ${ }^{5}$ As previously discussed, the permeability of educational spaces and practices is a focus of the application of third-space theory to educational practices. Primarily, this focusses on advocating for empowering the student through legitimating their learning, literacy practices, and expertise developed in "unofficial spaces" (Gutiérrez, 2008; McDougall \& Potter, 2017).

In our use of third-space theory here, we use it as a means of articulating the multivariate ways in which the "student" identity may be constructed or influenced. This will be explored through the rest of the literature, focusing initially on the construction of student-ascustomer, in doing so providing some context of HE more broadly.

\section{Student as customer}

The concept of "listening to the student voice"-implicitly if not deliberately-supports the perspective of student as "consumer," whereas "students as change agents" explicitly supports a view of the student as "active collaborator" and "co-producer," with the potential for transformation. (Dunne \& Owen, 2013, p. 4)

The characterisation of students-as-customers has been somewhat galvanised, if not outright codified, through increasing legislative oversight. HE providers in the UK are governed by the Consumer Rights Act 2015, and other consumer rights laws, such that student-university relationships are framed as a service-oriented transaction (Competition and Markets Authority, 2016). Though the student adoption of a consumerist attitude is "largely anecdotal" (Bunce, Baird, \& Jones, 2017, p. 1960), according to a survey of 1,000 students undertaken by Universities United Kingdom (UUK), 47\% of students identify themselves as customers of their university (Universities UK, 2017). 
What is worth considering here, however, is that students may be identifying themselves and may be identified as customers, but not at the exclusion of other identities. ${ }^{6}$ Indeed, there is an apparent conflict in the framing of students as customers as it potentially undermines traditional student-academic relationships (Williams, 2012; Woodall et al., 2014; Brown, 2015; Bunce et al., 2017). According to the UUK report (2017), "students want a more personal relationship with their university than the type of engagement they appear to associate with being a "customer'" (p. 6).

Accordingly, the framing of students as customers ${ }^{7}$ as somewhat oppositional to, or at least in tension with, academic identities captures a broader anxiety about the disruption to the "ethos of relationship between student and university" (Universities UK, 2017, p. 2).

Interestingly, if we were to temporarily ignore this student-as-customer identification, the notion of the student is still a site of tension.

\section{Student as proto-}

The imperative of "doing education" - as a keen, enthusiastic proto-academic seeking to attain a good final degree classification - often seems to be overridden by the imperative of "doing being a student" - as an average and/or indifferent student who does not stand out whilst interacting with other students.

(Attenborough 2011, p. 101)

In addition to the potential conflict between 'doing education' and 'doing being a student', the introduction of the student-as-customer framing invites, if not justifies, the framing of the student as something akin to the proto-professional-or "pre-professional" (Jackson, 2016). Part of the transactional value of HE in a marketised context is increased employability outcomes or industry readiness. Indeed, discussion of student identity in HE has become somewhat instrumentalist and viewed as a developmental necessity for industry readiness (Ashton, 2009, 2010; Daniels \& Brooker, 2014; Jackson, 2016). To an extent, this parallels the similar professional-academic identity amalgamation, or contestation, discussed by Celia Whitchurch (2008).

Of course, it is not possible to homogenise the student population. For instance, recent research has demonstrated a correlation between student-as-customer orientation and their identification as learners, the degrees they are studying, and whether they are responsible for paying tuition fees (Bunce et al., 2017). Further, it is beyond the scope of this article to outline all of the various identification processes given the contextual and ontological complexity. However, the purpose of this article is to illustrate that student identities are indeed complex. Unpacking student identity is an exercise in untying a Gordian knot (Latour, 1993)

Third-space theory elucidates this complexity by highlighting the intersection of multiple systems of meaning (e.g., governmental policy and markets, professional environments, and academic institutes) and the subsequent "hybridity" of identity (Gutiérrez, Baquedano-López, \& Tejeda, 1999; Gutiérrez, 2008). As we move on to discuss SaP as a pedagogic approach and ethos, the contribution of third-space theory we develop here is the treatment of the student identity as a site of potential resistance. As such, with the development of SaP projects it is necessary to be mindful that the nominal "student" is not a fixed notion. 


\section{Students as (well as) partners}

Each time the encounter with identity occurs at the point at which something exceeds the frame of the image, it eludes the eye, evacuates the self as site of identity and autonomy and-most important-leaves a resistant trace, a stain of the subject, a sign of resistance. (Bhabha, 1994 p. 45)

The foundational model put forward by Healy et al. (2014) loosely demarcates four categories of Student-as-Partners approach. These approaches are distinguished between students' engagement with teaching, learning, research, and the enhancement of such (Healy et al., 2014; Matthews, Cook-Sather, \& Healey, 2018). Further, they situate these approaches as dependent on a central process of cultivating a partnership learning-community and student participation within these communities. Within SaP literature, there are themes that are paralleled in third-space theory.

Values of authenticity, inclusivity, empowerment, and reciprocity as put forward by Healy et al. (2014) and others (Wenstone, 2013; Marie, 2018) in SaP are reflected in justifications for third-space educational practices (Gutiérrez, 2008; McDougall \& Potter, 2017). Additionally, this values-based approach to partnership is constructed as an active, integrative, and ongoing process, rather than demarcated activity (Mercer-mapstone et al., 2017). Further, the permeability of different systems of meaning leading to notions of "porous expertise" (McDougall \& Potter, 2015, 2017), resonates with the curation of "blended professionalism" in which student identity is drawn from academic, professional, and personal experiences (Healy et al., 2014).

As posited by Healy et al "partnership places students and staff in different roles and challenges the traditional hierarchical structure of learning and working relationships." (Healy et al., 2014, p. 28). As such, enactment of SaP and third-space theory as a pedagogic ethos is met with resistance as the curation of such requires "some challenging of the inherent power structures and assumptions, the habitus of the social actors of the space" (McDougall \& Potter, 2017, p. 43). Now, the distinction between SaP and third-space theory, and the contribution we believe third-space theory can make here, is the framing of identity as a site of resistance.

Though SaP does indeed discuss identity formation in comparable terms of intercontextual hybridity, its focus on identity formation is, relatively, unproblematised. That is, there is limited discussion about the ontological frictions that emerge as students move through and engage with different roles across multiple communities. Pedagogically, this formation of identity at the intersection of communities is valuable given SaP's framing of learning as "not just what the learner knows (which would be simply 'epistemological') but also who the learner is" (Wortham, 2004, p. 3). Critically however, identity formation according to Bhabha (1994) is an inherently reactive process. Identities are not formed pre-emptively, never a "self-fulfilling prophecy" (Bhabha, 1994, p. 45), nor a purely ontological consideration, but instead, "identification becomes, primarily, a response to questions of signification and desire, culture and politics" (Bhabha, 1994, p. 50)

There is of course consideration for the role of identity in SaP framed primarily as an "ontological act of being" (Bhabha, 1994, p. 50) with reference to a situated community of practice. Or as presented by Sfard, quoted in Cook-Sather (2010), "the identity of an individual, 
like an identity of a living organ, is a function of his or her being (or becoming) a part of a greater entity" (p. 6). Further, there is also discussion of the issues of inherent power dynamics at play in any SaP initiative, and a need to reflect on "the usefulness of current labels like 'staff' or 'students'" (Healy et al., 2014, p. 35). This research then extends this discussion, by using third-space theory, to not just question the usefulness of certain labels, but also their nominative power.

\section{METHODOLOGY}

As discussed, this research was conceived as a student-as-partners project undertaking the scholarship of teaching and learning (SoTL). Typically, students-as-partners SoTL projects are one-off projects that are academic-led, at least initially (Healy et al., 2014; Matthews et al., 2018; Mercer-Mapstone et al., 2017). This research is also reflective of this typical approach and is therefore subject to the same methodological and ethical quandaries. Though interesting and needed in the broader inquiry into the tensions of students-as-partners research, the discussion here is primarily methodological, although we do, perhaps inevitably, touch upon the role of third-space theory in conceptualising this research.

Participatory research methodologies typically provide a taxonomy of levels of participation (Fielding, 2001; Hart, 2008; Hunleth, 2011). Here, we undertook this research with two presuppositions, rather than fitting ourselves within a stratified "level" of participation. First, there is a dynamism to the degree of participation as the authors assigned responsibilities and defered to different perspectives, rationales, and experiences. ${ }^{8}$ Second, there are inherent relational expectations and power structures that may lead to "unwitting manipulation" of the student by the lecturer (Fielding, 2001, p. 123), so the shifting between different degrees of (un)equal collaboration may happen without us realizing it.

The two presuppositions presented here are informed by our understanding of third spaces and negotiated relationships and fluid identities. Throughout the article, both the students and lecturer co-authors openly reflect on this research, our methodological decisions, and our findings. Of course, this is not to absolve this project of any power-dynamic-related methodological issue, as to do so would be insincere. Rather, here we promote reflective acknowledgement of the positionality of the researchers that is necessitated in qualitative research generally. As Stephen Ball (1993) argues: "To write the researcher out of the report is to deny the dependency of the data on the researcher's presence" (p. 46)

Further to this methodological necessity, here we also encouraged reflective endnotes from all co-researchers as "there is a fluidity about the research stance which should be embraced for the richness of insights it offers" (Le Gallais, 2008, p. 153). To revisit a participatory taxonomy then, according to Fielding the authors here are both "data-sources" and "co-researchers" (Fielding, 2001). There is a final methodological consideration here that also speaks to the notion of third spaces, as there is a pre-existing relationship of mutual respect populated with reflective discussions of teaching and learning. Indeed, this research article isn't the first collective discussion of teaching and learning practices the authors have shared, though it is indeed the most formalised. 


\section{Research design}

To encourage shared reflection on participants' teaching and learning perceptions and experiences, we undertook student-led semi-structured interviews (Brinkmann, 2014; Bryman, 2015). This was also to ensure that the participants would, hopefully, feel more comfortable in sharing their honest experiences of the Cyber Security Management degree. Interviews were designed, conducted, and transcribed (including anonymisation) by a student co-author. ${ }^{9}$ Here we drew on Rubin and Rubin's (2005) framing of interviews as "conversations in which a researcher gently guides a conversational partner in an extended discussion" (p. 5).

As such, interviews adopted a purposefully conversational tone and the student interviewer drew on the work of Kvale (2008) in the formation of interview questions and in conducting the interview. ${ }^{10}$ To facilitate ethics in our research, our participants' names have been replaced with different names to preserve their anonymity (Opdenakker, 2006). A further consideration was over-rapport as the interviewer was familiar with the interviewees. Despite the risk that over-rapport runs of forming "a situation where the interviewee seeks to provide information that is thought to be expected or wanted by the researcher" (Ryan \& Dundon, 2008, p. 444), upon reflection this was not a significant issue.

Interviews followed a semi-structured format of open-ended exploratory questions (Merton, Fiske, \& Kendall, 1990) aimed towards encouraging reflections of their current experiences of $\mathrm{HE}$ and desirable experiences in reference to relationships with lecturers, with the duration of interviews ranging from 25 minutes and up to 60 minutes. In total, seven current Bournemouth University BSc Cyber Security Management students participated in this research, five of whom were in their final year (having returned from a placement), and two of whom had just entered their third (placement) year, ranging from ages between 20 and 25 .

\section{Thematic analysis}

The thematic coding process followed the phased approach outlined by Braun and Clarke (2006). Initial codes were generated through a semantic analysis of participant responses in combination with topics identified in the literature review. This included identity construction, relationships, internal-external comparisons, and pedagogic agency. In the initial stage, codes were stripped of presumptive values identified in the literature review such that they did not "narrow our analytical field of vision" (Braun \& Clarke, 2006, p.16). From this deductive, top-down starting point to identify codes, initial themes were generated through semantic analysis (Patton, 1990) of participant's framing of these topics.

All co-researchers in this study independently undertook an initial phase of thematic coding. ${ }^{11}$ Following the initial round of coding, we then collectively analysed these codes to come to a consensus. From this, we then analysed to draw out underlying presumptions and values that informed participant framing (Gee \& Handford, 2012) such that these themes could be related back to converged constructions of Students as Partners and third-spaces. This thematic coding was repeated to further "refine and define" the final findings (Braun \& Clarke, 2006). 


\section{DISCUSSION AND FINDINGS}

In undertaking this research, the authors identified that students exist within a nexus of social systems ${ }^{12,13}$. It is our intention here to present an honest discussion of students' perceptions and in doing so highlight the complexity of overlapping, and at times seemingly contradictory, systems of meaning. In addition, our intention here is to explicitly draw out the challenges to enacting collaborative SaP pedagogic practices. To begin, we first address an apparent experiential compartmentalisation in the form of decontextualised perspectives of student engagement. Interestingly, from a SaP and third-space perspective, this compartmentalisation is both external (i.e., between $\mathrm{HE}$ and professional experiences) and internal (i.e., across the modular structure of a degree).

From this perspective, participants also discussed a sense of de-individualisation as a result of typical pedagogic practices that are didactic by nature. Interestingly, the participants in this study viewed these pedagogic practices as not desirable, but a pragmatic necessity in HE. ${ }^{14}$ We then discuss a pervasive sense of hierarchy when participants discuss their relationships with their lecturers, which loops back to the initial discussion of the internal/external differentiation of $\mathrm{HE}$ and professional work. When discussing their relationships with lecturers, participants communicated in a professional-orientated rhetoric as a means of describing existing or desired relationships - though these relationships were still hierarchically framed. Further, for the participants who had returned from their placement year, they carried a professional identity that was not valued, or at least not acknowledged, when returning to HE.

\section{Decompartmentalised experience}

It was kind of like a factory in a way, "talk to one student and 'you get that way', talk to one student and 'they get that way.'” (Clare, 2nd Year)

Here, Clare discusses her dissatisfaction over the functional, didactic pedagogic experience with some higher education staff. As she articulates it, some lecturers would focus on efficient, managed interactions with students such that it was a case of lecturers explaining as quickly as possible in order to "move onto the next student" (Clare, 2nd Year). ${ }^{15,16}$ This feeling was shared by other participants, though they were somewhat sympathetic of this approach as a necessity due to student numbers. There is an interesting and repeated sense of compartmentalisation, or disinterest, in engaging with students beyond the confines of the immediate pedagogic activity.

According to participants, this compartmentalisation occurred on multiple levels. To begin, and this may be more symptomatic of the interdisciplinary nature and general administration of the degree itself, participants appeared to identify a lack of continuity across the degree's modular structure. Interestingly this was, again, something participants expressed resignation about, citing the limitations of large class sizes: "You look and you're like oh alright she has no idea where we are or what we've done or studied before.... you can't really expect that, right? You know, it's just a lot of people" (Arthur, 3rd Year).

In addition, there was a perceived compartmentalising of the student-lecturer dynamic within the lecture. The rigidity of the lecture, or as Clare (2nd Year) puts it, the "sterilised academic environment where there's just a lecturer talking," limits the capacity to form 
reciprocal relationships (Cook-Sather et al., 2014; Healy, 2014). Further, there was a frustration and juxtaposing of the apparent delineation of the lecture and non-lecture spaces: "Because right now what we think about lecturers is basically they are here and they give us lectures, then they can [disappear] and do their stuff. What do you do every day, read journals and the internet?" (Martin, 2nd Year).

Brian (3rd Year) writes "[lecturers are] all very friendly. They don't appear [so] from lectures and how they treat their lectures somehow." Indeed, part of the issue participants saw was the furtherance of perceived "power dynamics [that] can play out particularly strongly in classrooms" (Mercer-Mapstone et al., 2017, p. 17). That is, there was a reinforcement of lecturers as inaccessible or "some kind of mythical thing" (Arthur, 3rd Year), and, as an unfortunate consequence, the implicit positioning of the participants. That is, according to Clare (2nd Year) "the lecturer didn't say 'I'm going to talk down to you, I am better,' it just kind of happened." In countering this, there was a suggestion from participants for lecturers to share more of their personal histories.

Indeed, the dropping of formalities is representative of moving away from the rigidity of the previous student-academic relationship. In addition, the notion of humanising through sharing experiences speaks to a students' awareness of the lecture theatre as "having multiple, layered, and conflicting activity systems with various interconnections" (Guittiérrez, 2008, p. 151). As one participant writes:

The best lectures are the ones with Billy and with Bob and Joe, where everyone's just sort of chatting to one each other, right? They'll explain a topic like "this is a security thing, what do you think about it?" And everyone's like I like that and he's like "Oh I really like this, let me tell you of a time I used this." (Arthur, 3rd Year)

\section{Students as colleagues}

Like they are all different humans, well they are humans anyway not machines. (Martin, 2nd Year)

The desire from students for lecturers to share personal anecdotes, stories, and professional experiences can be viewed as a means of transcending, or permeating, the identifications of the lecture theatre. Indeed, the sharing of these anecdotes and research interests became an effective means of encouraging engagement. As one participant describes it, the lecture is "suddenly a conversation that [is] kind of like an interesting adventure through their history" (Brian, 3rd Year). This call for more "human" lecturers is interesting here. In part, this is related to a frequent reference to the desire to drop formalities and be friendly with lecturing staff, though this does not necessarily mean to be friends: "I'm not there to be friends with my supervisor. I want him to hate me and for me to hate him because he's making me work, which I think is the best way to be" (Martin, 2nd Year).

In addition, in their discussion of lecturers, there was a repeated desire for something akin to "humanising," or for lecturers to present themselves as "hybrids" and to make a virtue of "their existing complex identities" (Cook-Sather et al., 2014, p. 201), particularly with reference to external experiences. As discussed, this overlaps with students' desire for a decompartmentalised experience to offer different ways for students to relate and reciprocate. 
Further, there is an interesting parallel here, if not projection, in students' desire to have their external professional experiences acknowledged: "Maybe as well from the lecturer's point of view, they can understand [students] spent a year in industry. . . . I would hope that it's one step closer to being on their level" (Clare, 2nd Year).

It is worth acknowledging that Clare here is referring to professional experiences developed through professional placements-an option in this particular degree. It is interesting that "becoming" in this community-moving from the periphery to full members (Lave \& Wenger, 2007)-is legitimated through professional experiences. Further of importance to this research, these professional experiences hold greater currency in this community than academic experiences.

\section{Students as not 'just' students}

I mean in fourth year, they've started to realise we're adults now. I think some of the lecturers have done that now, because we've come back from placement and not because we've now been at uni for three years. (Brian, 3rd Year)

The community students are participating in then is complex and intersectional, and they appear to be developing a "'blended professionalism' where identity is drawn from academic, employment, and professional environments" (Gough et al. quoted in Healey et al., 2014 , p. 35). However, not all influencers of identity are weighted equally. It is here that we return to our initial discussion of Bhabha's framing of identity antagonisms at the intersection of different spaces. For instance, there is a comparative dismissal or stratification of experiences, activities, and legitimated knowledge from these different spaces, especially for students who have "been working in industry for a year and you know, you work like a real person" (Arthur, 3rd Year).

Additionally, there is the issue of prioritising one system of meaning over another. For instance, Brian shared his frustration over the current assessment approaches, stating that "I'm an IT geek that wants to expand my understanding of cybersecurity and implement it from a manager's point of view. I don't want to sit there writing an essay" (Brian, 3rd Year).

It is worth noting, of course, that this prioritisation of subject-specific and professional identities is perhaps just reflective of suggestions that students are more "career-focused than before"17 (Bunce et al., 2017, p. 1960; Universities UK 2017b), especially students in STEM degrees who are more likely to position themselves in relation to their professional identity. ${ }^{18}$ However, there is an additional issue here, as notions of professionalism were presented by participants as somewhat incompatible with the priorities of academia: "like the university is just assuming that every single person that comes into university is going to become an academic, stay in university, and go on to research" (Brian, 3rd Year).

As one participant suggested, if "you treat students as students you're not going to get very much out of them" (Brian, 3rd Year). It is worth considering the tensions and frustrations reported by participants in this study as they reflect on being confronted with external identifications that no longer resonate with their personal histories or strategies of self-hood. As is perhaps expected, there is a resistance to the framing of the "student" in as much as it diminutively positions students according to academic hierarchy, or at least a perceived 
academic hiearchy. For instance, as described by Clare (2nd Year), "a lot of the time I felt like I was being talked down to because 'I'm a student."'

\section{CONCLUSION AND RECOMMENDATIONS}

I'm spending nine grand a year to have the privilege of being in a room with some of, I will happily admit, some of the smartest people l'll probably ever get to meet, and I don't want to be spoken down to as a 5-year-old child. I want to have a proper adult conversation. (Brian, 3rd Year)

Within this quote, there is a neat representation of the complexities of student identification. There is self-positioning that is is framed with reference to broader notions of being a customer, and the entitlements that brings, whilst negotiating this with a reverence to the academics themselves. Further, drawing on a customer identity is itself an act of resistance to perceived identifications of immaturity, or not being seen as a "proper adult." The student identity is not immutable, nor is it possible to delineate it from identifications in situated communities and broader social contexts.

Now, given SaP's focus on elevating student voice through affording meaningful participation in a partnership learning-community, any potential resistance to the systems of meaning in this community must be considered. McDougall and Potter (2017) argue that "if none of the parties in communicative acts admits negotiation or complexity as preconditions of the production of meaning, then there is no room for maneuver which produces agency, action, or even, change in an educational setting" (p. 41).

Within the SaP community of educational practitioner-researchers, it is necessary to consider ourselves as one of these parties, even if our participation is very much on the periphery, taking the form of advocacy for different educational approaches. Therefore, in SaP, the use of "student" as a nominative term of reference is complex and a potential site of resistance that necessitates negotiation. Further, the framing of students becoming and being a member of a partnership learning-community is also a potential source of friction.

Our final point here is that this positioning of students at an intersection of professional and academic domains can itself be viewed as a third space that academics are, typically, unaware of. Further, there is value in this position as students participate in both spaces, whilst maintaining a degree of critical abstraction from both. Again, as Bhabha (1994) writes: "The transformational value of [third space] lies in the rearticulation, or translation, of elements that are neither the One... nor the Other... but something else besides, which contests the terms and territories of both" (p. 28).

It is fitting to end with the critique of students which reflects academic discussions of potential resistance by institutionalised systems of meaning to negotiable, hybrid identities and practices (Cook-Sather, 2010; McDougall \& Potter, 2018). Or as one participant suggests, enacting pedagogic changes requires "the galactic empire . . . to sign off on it and that takes 20 years" (Brian, 3rd Year). In addition, throughout participants' responses there is a locating of the "lecture" as a reinforcement of "fixed" identities and relationships, perceived or otherwise. Indeed, the authors share a similar, somewhat pragmatic, perspective suggested by the participants here. Despite the suggested importance and relational affordances of interacting 
with lecturers in non-formal settings, students identified the lecture theatre itself as being a necessary focus.

But the conclusion is it has to happen within the lecture or seminar. You can't change anything external. As either there's too many factors or it just won't impact enough. (Brian, 3rd Year)

Given the potential weight that formal teaching environments have in mediating identities and relational expectations, there is a need to focus on developing an open, negotiable position in the lecture theatre ${ }^{19}$ that validates the different "accounts [of] the interacting activity systems of people's everyday lives" (Gutiérrez, 1998, p. 151).

All research is presented here following approval from Bournemouth University's research ethics committee.

\section{NOTES}

1. Lecturer: For full disclosure, this research study was initiated by myself as a means of, perhaps narcissistically, exploring my attempts at adopting a third-space teaching style to promote educational engagement and participation.

2. Student: As a student I am subject to a range of teaching practices, some of which have been successful and others not so much, and so I was curious to see if this paper about third-space teaching styles could assist in identifying a solution for more engaging teaching styles and appease my curiosity to see if other students had similar experiences as I have had.

3. Lecturer: To the point of breaking perhaps.

4. Lecturer: Here, we do not wish to draw on the same critical, post-colonial framing of Bhabha as we are reluctant to frame students as "oppressed" in the same way post-colonial groups are. At the same time, we do not want to be dismissive of this work through our "selective" use of Bhabha's discussion.

5. Student: This "student" identification is immediately challenged after exposure to external business/professional environments. This is apparent later in the findings, which show that all the participants interviewed were either currently in or had come from industrial placements. 6. Student: With increasing tuition fees, many students (including myself) reflect upon our degrees as investments, whereby we pay universities a tuition fee to provide us a service in obtaining a degree.

7. Lecturer: Whenever a student has referred to themselves as a customer, or adopted that position, it always reads as an attempt to leverage whatever "power" they have in the situation. It is easy, and I have heard this frequently from colleagues, to dismiss this as a growing entitlement, rather than engaging with it as an expression of dissatisfaction through, perhaps the only, frame of reference students see as giving them agency.

8. Student: This may not have been achieved in the research discussions had they been led by a lecturer, rather than a student.

9. Student: At the beginning of each interview the student participants were ensured that only the co-author interviewing the participants would listen to their recording of the interview and 
would be the one to transcribe the recording, to ensure that no lecturer could identify them. This, I believe, led to more honest feedback about current and preferred teaching styles and learning experiences.

10. Student: I feel that due to knowing all the student participants in this study, led to an informal and relaxed interview environment, which was apparent with moments of humor. This informal environment contributed to the reduced possibility of demand characteristics.

11. Student: This allowed for impartial perspectives of themes to be identified at the initial stage then challenged, thus reducing potential bias of the identification of thematic codes.

12. Student: This made trying to contextualise separate core themes difficult, as there would be many connected themes, which if separated didn't capture the main themes that we wished to expand upon in this paper.

13. Lecturer: This, to me, mirrors some of the findings we draw later. The need to provide a linear structure in presenting this research is a little reductive of the complex overlap of themes, just as the linear structuring of educational processes is reductive of different systems of meaning.

14. Student: These pedagogic practices are not just consistent throughout HE but through all stages of institutional education.

15. Student: I myself have faced experiences where some interactions between myself and lecturers have been efficiently managed but have felt rushed and systematic, rather than humanised.

16. Lecturer: This is certainly something I feel as a lecturer-being forced into more functional or tokenistic engagements that sometimes feel like a regrettable inevitability.

17. Lecturer: Frequently, I find myself attempting to legitimise what I am teaching with reference to "this is was what employers want" or the CV-centered currency of a given theory, topic, or technique.

18. Student: With participants (and I included) who are now on or have just finished their placement year, the focus of professionalism is now more prevalent than the first two years at university.

19. Student: I agree that the lecture theatre is a necessary focus, as any relationship with your lecturer, be that positive or negative, is first established within this lecture theatre environment, as that is where the initial main contact with your lecturer begins.

\section{NOTE ON CONTRIBUTORS}

Ashley Kenway is a graduating undergraduate student at Bournemouth University where they studied for a BSC (Hons) in Cyber Security Management.

Phil Wilkinson is a Lecturer in Communications at Bournemouth University where he teaches across the fields of communication and cyber security.

Kieron Dowden-Smith is a third-year undergraduate student at Bournemouth University where they study BSC (Hons) Cyber Security Management. 


\section{REFERENCES}

Ashton, D. (2009). Making it professionally: Student identity and industry professionals in higher education. Journal of Education and Work, 22(4), 283-300.

https://doi.org/10.1080/13639080903290439

Ashton, D. (2010). Productive passions and everyday pedagogies: Exploring the industry-ready agenda in higher education. Art, Design \& Communication in Higher Education, 9(1), 4156. https://doi.org/10.1386/adch.9.1.41 1

Attenborough, F. T. (2011). 'I don't $\mathrm{f} * * *$ ing care!' Marginalia and the (textual) negotiation of an academic identity by university students. Discourse \& Communication, 5(2), 99-121. https://doi.org/10.1177/1750481310395447

Ball, S. (1993). Self-doubt and soft data: Social and technical trajectories in ethnographic fieldwork. In M. Hammersley (Ed.), Educational research: Current issues (vol. 1, pp. 3248). London: Open University Press.

Benson, S. (2010). "I don't know if that'd be English or not": Third space theory and literacy instruction. Journal of Adolescent \& Adult Literacy, 53(7), 555-563.

Bhabha, H. K. (1994). The location of culture. London: Routledge.

Braun, V., \& Clarke, V. (2006). Using thematic analysis in pscyhology. Qualitative Research in Psychology, 3(2), 77-101.

Brinkmann, S. (2014). Interview. In T. Teo (Ed.), Encyclopedia of critical psychology. Springer, 1008-1010. https://doi.org/10.1007/978-1-4614-5583-7 161

Brown, R. (2015). The marketisation of higher education: Issues and ironies. New Vistas, 1(1). Retreived from http://eprints.bournemouth.ac.uk/14011/1/licence.txt

Bryman, A. (2015). Social research methods (4th ed.). Oxford: Oxford University Press.

Bunce, L., Baird, A., \& Jones, S. E. (2017). The student-as-consumer approach in higher education and its effects on academic performance. Studies in Higher Education, 42(11), 1958-1978. https://doi.org/10.1080/03075079.2015.1127908

Competition and Markets Authority. (2016). Consumer law compliance review: Higher Education undergraduate sector findings report. London. Retrieved from https://assets.publishing.service.gov.uk/media/5791e595e5274a0da300019f/complianc e-review-findings-higher-education-undergraduate-sector.pdf

Cook-Sather, A., 2010. Students as Learners and Teachers: Taking Responsibility, Transforming Education, and Redefining Accountability. Curriculum Inquiry, 40 (4), 555-575.

Cook-Sather, A., Bovill, C., \& Felten, P. (2014). Engaging students as partners in learning and teaching: A guide for faculty. San Francisco: Jossey Bass.

Daniels, J., \& Brooker, J. (2014). Student identity development in higher education: Implications for graduate attributes and work-readiness. Educational research, 56(1), 65-76. https://doi.org/10.1080/00131881.2013.874157

Dunne, E., \& Owen, D. (Eds.). (2013). Student engagement handbook: Practice in higher education. Bingley, UK: Emerald Group Publishing.

Fielding, M. (2001). Students as radical agents of change. Journal of Educational Change, 2(2), 123-141. https://doi.org/10.1023/A:1017949213447

Le Gallais, T. (2008). Wherever I go there I am: Reflections on reflexivity and the research 
stance. Reflective Practice: International and Multidisciplinary Perspectives, 9(2), 145 155. https://doi.org/10.1080/14623940802005475

Gee, J., \& Handford, M. (Eds.). (2012). The Routledge handbook of discourse analysis. New York: Routledge.

Guattari, F., \& Deleuze, G. (1987). A thousand plateaus. Minneapolis: University of Minnesota Press.

Gutiérrez, K. D. (2008). Developing a sociocritical literacy in the third space. Reading Research Quarterly, 43(2), 148-164. https://doi.org/10.1598/RRQ.43.2.3

Gutiérrez, K. D., Baquedano-López, P., \& Tejeda, C. (1999). Rethinking diversity: Hybridity and hybrid language practices in the third space. Mind, Culture, and Activity, 6(4), 286-303. https://doi.org/10.1080/10749039909524733

Hart, R. A. (2008). Stepping back from 'the ladder': Reflections on a model of participatory work with children. In A. Reid, B. Jensen, J. Nikel, \& V. Simovska (Eds.), Participation and learning: Perspectives on education and the environment, health and sustainability (pp. 1-18). London: Springer, 19-31.

Healy, M., Flint, A., \& Harrington, K. (2014). Engagement through partnership: Students as partners in learning and teaching in higher education. York: The Higher Education Academy. Retrieved from https://www.heacademy.ac.uk/knowledge-hub/engagementthrough-partnership-students-partners-learning-and-teaching-higher

Hunleth, J. (2011). Beyond on or with: Questioning power dynamics and knowledge production in 'child-oriented' research methodology. Childhood, 18(1), 81-93.

https://doi.org/10.1177\%2F0907568210371234

Jackson, D. (2016). Re-conceptualising graduate employability: The importance of preprofessional identity. Higher Education Research \& Development, 35(5): 925-939. https://doi.org/10.1080/07294360.2016.1139551

Kvale, S. (2008). Doing interviews. London: Sage. Latour, B., 1993. We have never been modern. Cambridge, Massachusetts: Harvard University Press.

Lave, J., \& Wenger, E. (1991). Situated Learning: Legitimate Peripheral Participation. Cambridge, UK: Cambridge University Press.

Marie, J. (2018). The relationship between research-based education and student-staff partnerships. In V. Tong, A. Standen, \& M. Sotiriou (Eds.), Shaping higher education with students (pp. 30-40). London: UCLPress.

Matthews, K. E., Cook-Sather, A., \& Healy, M. (2018). Connecting learning, teaching and research through student-staff partnerships: Toward universities as egalitarian learning communities. In V. Tong, A. Standen, \& M. Sotiriou (Eds.), Shaping higher education with students (pp. 23-30). London: UCL Press.

McDougall, J., \& Potter, J. (2015). Curating media learning: Towards a porous expertise. ELearning and Digital Media, 12(2), 199-211. https://doi.org/10.1177\%2F2042753015581975

McDougall, J., \& Potter, J. (2017). Digital media, culture and education. London: Palgrave Macmillan. 
Mercer-Mapstone, L., Dvorakova, S. L., Matthews, K. E., Abbot, S., Cheng, B., Felten, P., Knorr, K., Marquis, E., Shammas, R., \& Swaim, K. (2017). A systematic literature review of students as partners in higher education. International Journal for Students as Partners, 1(1), 1-23. https://doi.org/10.15173/ijsap.v1i1.3119

Merton, R., Fiske, M., \& Kendall, P. (1990). The focused enterview: A manual of problems and procedures. New York: Free Press.

Moje, E., Mclntosh Ciechanowski, K., Kramer, K., Ellis, L., Carrillo, R., \& Collazo, T. (2004). Working toward third space in content area literacy: An examination of everday funds of knowledge and Discourse. Reading Research Quarterly, 39(1), 38-70. https://doi.org/10.1598/RRQ.39.1.4

Opdenakker, R. (2006). Advantages and disadvantages of four interview techniques in qualitative research. Forum Qualitative Sozialforschung/Forum: Qualitative Social Research, 7(4). Retrieved from http://www.qualitativeresearch.net/index.php/fas/article/view/175/391

Patton, M. (1990). Qualitative evaluation and research methods (2nd ed). Newbury Park: SAGE. Rubin, H. J. \& Rubin, I. S. (2005). Qualitative interviewing: The art of hearing data (2nd ed.). New York: Sage Publication.

Ryan, P., \& Dundon, T. (2008). Case research interviews: Eliciting superior quality data. International Journal of Case Method Research \& Application, (4).

Universities UK. (2017). Education, consumer rights and maintaining trust: What students want from their university. London. Retrieved from https://www.universitiesuk.ac.uk/policyand-analysis/reports/Pages/what-students-want-from-their-university.aspx

Wenstone, R., (2013). A manifesto for partnership. London.

Whitchurch, C. (2008). Shifting identities and blurring boundaries: The emergence of third space professionals in UK higher education. Higher Education Quarterly, 62(4), 377-396. https://doi.org/10.1111/j.1468-2273.2008.00387.x

Williams, J. (2013). Consuming higher education: Why learning can't be bought. London: Bloomsbury

Woodall, T., Hiller, A., \& Resnick, S. (2014). Making sense of higher education: Students as consumers and the value of the university experience. Studies in Higher Education, 39(1), 48-67. https://doi.org/10.1080/03075079.2011.648373

Wortham, S. (2004). The interdependence of social identififcation and learning. American Education Research Journal, 41(3), 715-750.

https://doi.org/10.3102\%2F00028312041003715 